\title{
Rola rozpoznania geoprzestrzennego w polityce bezpieczeństwa Unii Europejskiej
}

Aвstract: Geospatial intelligence is an intelligence discipline which, thanks to technological development, has exerted an increasing impact on national security policies and international cooperation. Building on imagery acquired through the use of optical, radar and telemetric equipment, it gives access to current, multi-layered situational knowledge about physical features and natural events on Earth, which is important in the decision-making processes conducted by states, institutions of state, and international organizations formed by states. This chapter presents the process of institutionalization of geospatial intelligence at the level of an international organization, on the example of the European Union. By characterizing the institutional arrangements and operational activities undertaken by this organization, the author offers arguments for the thesis about the growing role of geospatial intelligence in raising strategic awareness among EU and Member States decision-makers in key areas of European security.

Keywords: European Union, security, geospatial intelligence, Frontex, EU Satellite Centre 


\section{Wprowadzenie}

Współczesna polityka bezpieczeństwa oraz wynikające z niej formy zarządzania i kierowania $w$ wymiarze cywilnym i wojskowym $w$ coraz szerszym zakresie określane są przez zdolności i możliwości uzyskania jak najpełniejszej świadomości sytuacyjnej w procesach podejmowania decyzji. Reagowanie na pojawiające się zagrożenia i wyzwania, budowanie systemowej odporności na kryzysy i zaburzenia, a także planowanie strategiczne i operacyjne $w$ sferze bezpieczeństwa są nieefektywne, niepelne lub wręcz niewykonalne bez sprawnego funkcjonowania systemów pozyskiwania, skupiania, przetwarzania i analizowania danych i informacji dotyczących kluczowych elementów bezpieczeństwa w wymiarze lokalnym, narodowym i międzynarodowym. Zorganizowane i zinstytucjonalizowane czynności przetwarzania oraz zarządzania informacją i danymi zazwyczaj przybierają postać rozpoznania i analizy wywiadowczej, które służą uzyskaniu jak najszerszej wiedzy w celu optymalizacji procesów decyzyjnych. W wymiarze bezpieczeństwa narodowego rozpoznanie $\mathrm{i}$ analiza wywiadowcza są domeną państwa, a konkretnie wyspecjalizowanych służb i agencji, które w rozbudowanych formach instytucjonalno-organizacyjnych przybierają postać narodowych wspólnot wywiadowczych. Działalność wywiadowcza nie jest zarezerwowana dla państw, zajmują się nią także organizacje międzynarodowe (jak np. NATO i UE), a także liczne podmioty pozapaństwowe (np. organizacja terrorystyczna o nazwie Państwo Islamskie) i prywatne (tzw. wywiadownie gospodarcze praktykujące business intelligence).

Jedną z klasycznych form działalności wywiadowczej jest wykonywanie fotografii osób, przedmiotów, obiektów, miejsc i obszarów do celów przetwarzania, porównywania i analizy zarejestrowanych danych. Czynności tego typu przeszly glęboką ewolucję wraz z rozwojem technologii rejestracji, obróbki i przetwarzania danych obrazowych. Rozwój technologii optycznych, optoelektronicznych, a także komputerowych, telekomunikacyjnych i satelitarnych doprowadzil do niebywalego postępu w rozwoju wywiadu geoprzestrzennego (geospatial intelligence - GEOINT) i rozpoznania obrazowego (imagery intelligence - IMINT). Niniejszy rozdział podejmuje problematykę wykorzystania powyższych metod w procesie formułowania i realizacji polityki bezpieczeństwa UE. Zakładając, na podstawie wniosków $\mathbf{z}$ wcześniejszych badań, ze w ramach UE funkcjonuje europejska wspólnota wywiadowcza sui generis ${ }^{1}$, tezą rozwijaną $\mathrm{w}$ tym artykule jest rosnąca rola rozpoznania geoprzestrzennego $w$ formowaniu świadomości strategicznej decydentów na poziomie UE i państw członkowskich,

1 Zob. A. Gruszczak, Europejska wspólnota wywiadowcza. Prawo - instytucje - mechanizmy, Kraków 2014; idem, Intelligence Security in the European Union. Building a Strategic Intelligence Community, London-New York 2016. 
determinującej strategię, politykę i działania w kluczowych obszarach bezpieczeństwa UE. Metody zastosowane $w$ badaniach prezentowanych $w$ tym rozdziale obejmuja analizę instytucjonalną, metodę historyczną i metodę porównawczą. $\mathrm{Na}$ podstawie wnioskowania dedukcyjnego struktura tego rozdziału obejmuje zarys definicyjno-koncepcyjny rozpoznania geoprzestrzennego, historyczno-instytucjonalną analizę procesu formowania zdolności rozpoznania geoprzestrzennego w UE, rolę Centrum Satelitarnego UE, a następnie studia przypadku dotyczące trzech wybranych form aktywności UE: systemu EUROSUR, operacji Sophia i operacji Atalanta.

\section{Rozpoznanie geoprzestrzenne: zarys definicyjno-koncepcyjny}

Rozpoznanie geoprzestrzenne (wywiad geoprzestrzenny) ${ }^{2}$ obejmuje cztery podstawowe elementy ${ }^{3}$ :

1. Obraz (zobrazowanie, odzwierciedlenie), będący przedstawieniem naturalnych lub ludzkich wytworów (obiektów), ich cech i form aktywności, w formie danych pozycyjnych pozyskanych w momencie utrwalenia stalych lub ujawnionych przez dany obiekt cech i form zachowań ${ }^{4}$.

2. Środki techniczne, obejmujące urządzenia do teledetekcji danych obrazowych (kamery, radary, sonary, lasery), ich nośniki (satelity, bezzałogowe statki latające, samoloty zwiadowcze, okręty nawodne i podwodne), stacjonarne wieże obserwacyjne, stacje radarowe), środki transmisji danych (lącza przewodowe i bezprzewodowe) oraz oprogramowanie (programy szyfrujące przesył danych, przetwarzające i analizujące dane $\mathrm{i}$ informacje).

3. Przetwarzanie i analiza, polegająca na zestawieniu, porównywaniu, kategoryzacji i georeferencji (orientacji w przestrzeni fizycznej) standardowych i specjalistycznych analogowych i cyfrowych danych i informacji geoprzestrzennych, w tym obrazów

$2 \mathrm{~W}$ j. angielskim geospatial intelligence - GEOINT.

3 Na podstawie: Geospatial Intelligence (GEOINT) Basic Doctrine, National Geospatial Intelligence Agency, Washington, D.C., September 2006, https://www.nga.mil/ProductsServices/ Documents/170901-038_GEOINT_Basic_Doctrine_Pub_1.pdf, 9 V 2014; T. Bajerowski, A. Kowalczyk, Metody geoinformacyjnych analiz jawnoźródlowych w zwalczaniu terroryzmu, Olsztyn 2013; National Research Council, Priorities for GEOINT Research at the National Geospatial-Intelligence Agency, Washington, D.C. 2006; J. R. Clapper, Jr., Imagine the power of GEOINT, ${ }_{n}$ Pathfinder

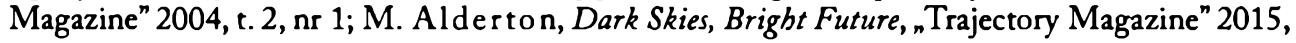
t. $32, \mathrm{nr} 3$.

4 Interesującym rysem koncepcji GEOINT skodyfikowanej w Stanach Zjednoczonych jest wylączenie fotografii wykonanych ręcznym aparatem lub w sposób ukryty (szpiegowski). Zob. U.S. Code, tytul 10, par. 467, pkt 1 (B), https://www.law.cornell.edu/uscode/text/10/467, 24 VII 2018. 
wielospektralnych, danych geologicznych, geograficznych, hydrologicznych, meteorologicznych i ekologicznych, a także zastosowaniu technik i metod wizualizacji i analizy przestrzennej (statycznej i dynamicznej).

4. Wykonanie i rozpowszechnianie produktów wywiadowczych w postaci tabelarycznej lub graficznej, przede wszystkim: map (jedno-, dwu- i trójwymiarowych), modeli, atlasów, diagramów, schematów, wykresów. Rozpowszechnianie opiera się na formalnych, zabezpieczonych i kompatybilnych systemach informatyczno-komunikacyjnych, a także autoryzacji podmiotów (indywidualnych i instytucjonalnych). Podejmując próbę zdefiniowania rozpoznania geoprzestrzennego, należy zwrócić uwagę, iż w literaturze przedmiotu mocno zakorzeniła się definicja zawarta w Kodeksie Stanów Zjednoczonych, włączona następnie do amerykańskiej doktryny wywiadu geoprzestrzennego oraz koncepcji operacyjnej sił zbrojnych USA ${ }^{5}$. Brzmi ona następująco: „pozyskanie, przetwarzanie, analiza i wykorzystanie danych obrazowych w celu opisu, oceny i wizualnej prezentacji cech fizycznych oraz działań odnoszących się do środowiska geograficznego na kuli ziemskiej" ${ }^{\text {6 }}$. Podobnie brzmi definicja pojawiająca się w dokumentach UE: „GEOINT (wywiad geoprzestrzenny) obejmuje kompleksową analizę informacji geoprzestrzennej w celu opisu, oceny i wizualnego przedstawienia cech fizycznych i geograficznie określonych działań na Ziemin ${ }^{\text {n7. Polscy }}$ eksperci w dziedzinie studiów wywiadowczych i bezpieczeństwa podają następującą definicję: ${ }_{n}$ wykorzystywanie i analiza obrazów oraz informacji geoprzestrzennych w celu opisania, oceny i wizualizacji cech fizycznych i geograficznych, mówiących o działaniach podejmowanych na ziemin ${ }^{\text {ng }}$.

Powyższe definicje bliższe są pojęciu informacji geoprzestrzennej, kładąc nacisk na odwzorowanie fizycznych cech środowiska geograficznego. Aspekt analityczno-wywiadowczy jest uwypuklony przez T. Bajerowskiego i A. Kowalczyk, którzy podkreślają, że szczególna wartość metod i systemów geoinformacyjnych polega na zaawansowanym wykorzystaniu geoinformacji i danych wizualnych do tworzenia dynamicznych i interaktywnych produktów wywiadowczych' . Rozpoznanie obrazowe umożliwia pozyskiwanie i przetwarzanie danych przy zastosowaniu technologii i urządzeń zobrazowania (fotograficznego, optoelektronicznego, radarowego i radiolokacyjnego). Niemniej

5 Zob. R. E. Barrowman, Geospatial Intelligence. The New Intelligence Discipline, Noint Force Quarterly" 2007, nr 44, s. 14-18.

6 U.S. Code, par. 467, pkt 1 (B).

7 EU SatCen Annual Report 2015, Luxembourg 2016, s. 10.

8 K. Liedel,T. Serafin, Otwarte źródla informacji w dziatalności wywiadowczej, Warszawa 2011, s. 29-30.

9 T. Bajerowski, A. Kowalczyk, op. cit., s. 55. 
w polityce bezpieczeństwa narodowego, a także w stosunkach międzynarodowych, liczy się trafność decyzji i skuteczność wynikających z nich działań będąca efektem połączenia wiedzy i doświadczenia (a czasami intuicji) decydenta $z$ optymalną strategiczną świadomością sytuacyjną. Wywiad geoprzestrzenny, tworzony na podstawie oddziałujących na zmysł wzroku obrazów, wzmacnia reakcje poznawcze i stymuluje procesy kognitywne decydenta, wpływając na zachowania decyzyjne jednostek ${ }^{10}$.

Zatem w kontekście interesów bezpieczeństwa narodowego państwa, jak też polityki bezpieczeństwa organizacji międzynarodowych (w szczególności tworzących tzw. wspólnoty bezpieczeństwa), wywiad geoprzestrzenny można zdefiniować jako:

Zespól celowych i zorganizowanych czynności zorientowanych na pozyskiwanie, gromadzenie, przesyłanie, przetwarzanie i analizę danych geoinformacyjnych przy wykorzystaniu specjalistycznych metod i narzędzi w celu tworzenia jednolitych produktów wywiadowczych kształtujących świadomość sytuacyjną wspierającą procesy podejmowania decyzji w dziedzinie bezpieczeństwa.

\section{Instytucjonalizacja rozpoznania geoprzestrzennego w Unii}

\section{Europejskiej}

Zagadnienie rozpoznania (wywiadu) geoprzestrzennego pojawiło się w ramach procesu integracji europejskiej na początku lat 90 . XX w. w związku z aktywacją wspólpracy w dziedzinie bezpieczeństwa oraz rozwojem technologii i systemów geoinformacyjnych, w szczególności tych, które miały zastosowanie militarne ${ }^{11}$. Interwencja sił ONZ w Zatoce Perskiej w latach 1990-1991, w następstwie irackiej inwazji i aneksji Kuwejtu, ukazała ogromne znaczenie nowoczesnych technologii w planowaniu i prowadzeniu działań wojskowych na podstawie elektronicznego rozpoznania pola walki. Udział Stanów Zjednoczonych w siłach ONZ umożliwił wsparcie operacji przeciwko siłom irackim poprzez zastosowanie technologii rozpoznania satelitarnego, precyzyjnego pozycjonowania (GPS), obserwacji powietrznej, dynamicznej radiolokacji (AWACS). Pod wrażeniem działań w Zatoce Perskiej ministrowie spraw zagranicznych i obrony państw członkowskich Unii Zachodnioeuropejskiej (UZE) uzgodnili powołanie "ośrodka interpretacji danych satelitarnych"12. W czerwcu 1991 r. zapadla decyzja

10 Por. R. J. Heue r, Jr., Psychology of Intelligence Analysis, Washington, D.C. 1999.

1 Szerzej w: A. Gruszczak, Europejska wspólnota wywiadowcza..., roz. 4.

12 Meeting of the WEU Council of Ministers, Paris, 10 December 1990. Communique, http://www.weu. int/documents/901210-2en.pdf, 14 VI 2004. Por. B. Molard, How the WEU Satellite Centre could 
o utworzeniu Centrum Satelitarnego UZE, którego bezpośrednim zadaniem było szkolenie ekspertów w interpretacji zdjęć satelitarnych, kompilacja i opracowywanie dostępnych danych geoinformacyjnych oraz udostępnianie tych danych państwom członkowskim UZE, w szczególności do celów kontroli porozumień rozbrojeniowych, monitorowania kryzysów i obserwacji środowiska naturalnego ${ }^{13}$.

Centrum Satelitarne UZE (Satellite Centre - SatCen) zainaugurowało swą działalność 28 IV 1993 r. Na początku 1996 r. SatCen otrzymał pierwsze zdjęcia wysokiej rozdzielczości w ramach programu wspólpracy Hélios 1 z udziałem Francji, Hiszpanii i Włoch. Poczynił także pierwsze zakupy zdjęć satelitarnych od komercyjnych dostawców. Pierwszą poważną próbą zdolności operacyjnych centrum były zamieszki w Albanii na początku 1997 r., które doprowadziły do interwencji sil wojskowych pod egidą Organizacji Bezpieczeństwa i Wspólpracy w Europie (OBWE). SatCen dostarczył Radzie UE kompletny obraz sytuacyjny na podstawie pozyskanych danych satelitarnych, przetworzonych przez analityków Centrum ${ }^{14}$. Reforma polityki bezpieczeństwa i obrony UE $w$ traktacie amsterdamskim oraz przeniesienie realizacji zadań petersberskich z UZE do UE spowodowały wlączenie Centrum Satelitarnego w struktury organizacyjne UE w 2000 r. Obecnie Centrum Satelitarne UE funkcjonuje na podstawie decyzji nr 2014/401/WPZiB z 26 VI 2014 r. ${ }^{15}$ Podstawowym zadaniem jest wspieranie procesu podejmowania decyzji w ramach wspólnej polityki bezpieczeństwa i obrony UE (WPBiO), w tym w operacjach zarządzania kryzysowego, poprzez dostarczanie odpowiednich produktów i usług przy wykorzystaniu obrazów satelitarnych i lotniczych oraz danych dodatkowych.

Dostęp do wysokiej jakości zdjęć lotniczych i satelitarnych oraz innych danych geoinformacyjnych jest od początku działalności Centrum Satelitarnego zasadniczym problemem natury politycznej, technologicznej, komunikacyjnej i finansowej. Dostarczyciele danych obrazowych należą do trzech kategorii pod względem statusu i celów działalności: państwowej, publicznej i komercyjnej. Do pierwszej kategorii należą systemy satelitarne zbudowane, utrzymywane i kierowane przez rządy państw czlonkowskich bezpośrednio lub za pośrednictwem specjalnych agencji rządowych.

belp in the development of a European intelligence policy, [w:] Towards a European intelligence policy, red. A. Politi, ${ }_{n}$ Chaillot Paper ${ }^{n}, n r$ 34, Institute of Security Studies of the WEU, Paris, December 1998. 13 Ministerial Decision setting-up of a WEU Satellite Centre taken at Vianden, Luxembourg, 27 June 1991, http://www.weu.int/documents/910627en.pdf, 14 VI 2004.

14 B. Molard, op. cit., s. 27.

15 Decyzja Rady 2014/401/WPZiB z dnia 26 czerwca 2014 r. w sprawie Centrum Satelitarnego Unii Europejskiej $i$ uchylenia wspolnego dziatania 2001/555/WPZiB w sprawie ustanowienia Centrum Satelitarnego Unii Europejskiej, „Dziennik Urzędowy Unii Europejskiej” (dalej: Dz.Urz. UE) 2014, nr L 188, s. 73. 
Do drugiej kategorii należy zaliczyć ogólnie dostępne, należące do otwartych źródeł informacji, zdjęcia satelitarne i lotnicze. W trzeciej kategorii mieszczą się dostawcy komercyjni, którzy odplatnie oferują zdjęcia satelitarne i radarowe wykonane przez należące do nich satelity obserwacyjne.

Kluczowe znaczenie mają dane geoinformacyjne pochodzące od rządów państw członkowskich UE. $\mathrm{Na}$ pierwszy plan wysuwa się program Hélios realizowany od 1993 r. przez konsorcjum trzech krajów: Francji, Wloch i Hiszpanii. Dwa satelity wyposażone w kamery optyczne o wysokiej rozdzielczości od 2008 r. udostępniają obrazy satelitarne SatCenowi. Rozszerzeniem programu Hélios było francusko-niemieckie porozumienie z 2002 r. o budowie systemu satelitarnego SAR-Lupe, obejmującego stację naziemną i pięć satelitów wyposażonych w urządzenia radarowe $\mathrm{z}$ syntetyczną aperturą, umożliwiające tworzenie obrazów o wysokiej rozdzielczości nieruchomych obiektów. W 2013 r. uruchomiono bezpieczne lącze między stacją naziemną SAR-Lupe a SatCenem umożliwiające bezpośredni dostęp do niejawnych danych satelitarnych.

Wloski system satelitarny Cosmo-SkyMed, dostarczający radarowych obrazów geoprzestrzennych, ma podwójne przeznaczenie: cywilne i wojskowe. Obrazy i dane geoinformacyjne są $\mathrm{w}$ razie potrzeby przekazywane za zgodą rządu włoskiego partnerom $z$ innych krajów członkowskich UE oraz Centrum Satelitarnemu UE. Po uregulowaniu kwestii dostępu do danych niejawnych od 2011 r. satelity Cosmo-SkyMed dostarczają dane obrazowe o przeznaczeniu wojskowym. Od 2016 r. dane te przesyłane są szybkim i bezpiecznym łączem transmisyjnym między stacją naziemną systemu a SatCenem. Projekt Pléiades powstał $z$ inicjatywy Francji i Wloch i jest realizowany od 2003 r. przez francuską agencję kosmiczną CNES. Satelity Pléiades 1A i Pléiades 1B - wyposażone w cyfrowe sensory optyczne wysokiej rozdzielczości, umożliwiające stereoskopową wizualizację powierzchni Ziemi - zostały umieszczone na orbicie geostacjonarnej w 2011 i 2012 r. Od 2014 r. dysponują pełną funkcjonalnością, dostarczając średnio tysiąc zobrazowań wysokiej rozdzielczości dziennie ${ }^{16}$. W powiązaniu z obrazami dostarczanymi przez francuskie satelity SPOT SatCen posiada zdolność analizy geoprzestrzennej w czasie rzeczywistym w celu monitorowania procesów toczących się na obszarach o szczególnym znaczeniu dla bezpieczeństwa UE.

SatCen uczestniczy także w projekcie Copernicus, realizowanym przez Europejską Agencję Kosmiczną, którego celem jest budowa, umieszczenie na orbicie i wykorzystywanie do obserwacji Ziemi satelitów pracujących wyłącznie dla UE. Dotychczas na orbitę okołoziemską wyniesiono sześć satelitów serii Sentinel wyposażonych

16 Zob. Pleiades-HR (High-Resolution Optical Imaging Constellation of CNES), https://earth.esa. int/web/eoportal/satellite-missions/p/pleiades, 24 VIII 2018. 
w aparaturę optyczną, radarową i telemetryczną do stałego obserwowania powierzchni lądów i mórz, głównie pod kątem wykrywania zagrożeń dla środowiska naturalnego oraz bezpieczeństwa ludzi ${ }^{17}$.

Ponadto SatCen korzysta odplatnie z różnorakich usług geoinformacyjnych świadczonych przez prywatne firmy z państw członkowskich UE oraz spoza UE. Obejmują one zobrazowanie wyznaczonego obszaru, obrazy wielospektralne, dane geologiczne, geofizyczne, hydrologiczne, meteorologiczne i ekologiczne, a także wizualizacje i analizy przestrzenne. Dodatkowym źródłem danych geoinformacyjnych są zasoby otwarte, zazwyczaj uzupełniające wytworzony obraz sytuacyjny lub gotowy materiał analityczny.

Centrum Satelitarne UE wykorzystuje cale spektrum metod analizy geoinformacyjnej, dążąc do jak najlepszego dostosowania produktów wywiadowczych do potrzeb skutecznego wsparcia działań prowadzonych w ramach WPBiO, a także zarządzania granicami zewnętrznymi państw członkowskich UE, koordynowanych przez Agencję Europejskiej Straży Granicznej i Przybrzeżnej - Frontex.

Podstawową metodą wykorzystywaną przez SatCen jest analiza i przetwarzanie obrazów otrzymywanych przy użyciu sensorów optycznych i urządzeń radarowych, a następnie ich korelacja z danymi jawnoźródłowymi pozyskiwanymi przez tę agencję i otrzymywanymi od państw czlonkowskich. Wynikiem tego jest wizualizacja danych w formie map wektorowych lub rastrowych, a także trójwymiarowych modeli geoprzestrzennych. Możliwość komputerowego nakładania warstw tematycznych pozwala na przygotowanie unikatowych map zawierających dużą liczbę atrybutów jakościowych, szczególnie przydatnych do dalszej analizy wywiadowczej. Modelowanie trójwymiarowe jest przydatne zarówno w zarządzaniu sytuacjami kryzysowymi, jak też w planowaniu i przygotowaniu operacyjnym, a także specjalistycznym szkoleniu funkcjonariuszy UE uczestniczących w misjach i operacjach w ramach WPBiO.

Różnorodność danych geoinformacyjnych oraz metod ich przetwarzania i analizy przez SatCen, a także odbiorców i użytkowników gotowych produktów (zarówno instytucji i agencji UE, jak też innych organizacji międzynarodowych) wplywa na ich kategoryzację. Podstawowe produkty przygotowane przez SatCen obejmują:

- raporty na gorąco, sporządzane w odpowiedzi na zgloszony pilnie wniosek, odnoszące się do nagle zaistniałej sytuacji kryzysowej (np. incydentu zbrojnego, kryzysu politycznego o szerokim zasięgu, klęski żywiołowej) i mające na celu dostarczenie aktualnej informacji i oceny sytuacyjnej;

17 Zob. Sentinel Satellites, http://www.copernicus.eu/main/sentinels, 24 VIII 2018. 
- notatki, przygotowywane w ciągu kilku dni od zlożenia wniosku, zawierające zinterpretowane dane obrazowe, zwykle mające postać wyróżnionych na zdjęciu atrybutów lub wypunktowanych i krótko opisanych cech danego obiektu lub obszaru;

- raporty, zlożone produkty wywiadowcze, wykorzystujące dane wieloźródłowe (zobrazowanie satelitarne, dane geoinformacyjnych, dane powiązane, ukierunkowane tematycznie dane jawnoźródłowe) do porównania, przetwarzania i analizy pod kątem wyznaczonego parametru bezpieczeństwa. Ich celem jest dostarczenie w miarę kompletnego obrazu sytuacyjnego w wymiarze przestrzenno-problemowym, skupionym na geofizycznych, infrastrukturalnych, klimatycznych lub demograficznych aspektach danego problemu;

- studia, zawierające syntetyczną wiedzę o wybranym zagadnieniu z zakresu zarządzania kryzysowego, operacji pokojowych lub misji cywilnych i wojskowych, ewentualnie ogólnych problemów bezpieczeństwa globalnego. Są to problemowe opracowania wykorzystujące elementy analizy geoprzestrzennej, gotowych produktów wywiadowczych oraz tematycznych opracowań dostępnych ze źródeł otwartych;

- mapy cyfrowe, tworzone na podstawie danych bazowych, które po dalszej obróbce i przetwarzaniu przez SatCen lub innych uprawnionych odbiorców służą uzyskaniu wielowarstwowego, sprofilowanego obrazu według wyznaczonych parametrów.

\section{Rozpoznanie geoprzestrzenne w działalności agencji Frontex}

Wśród odbiorców produktów Centrum Satelitarnego UE dużą aktywnością wykazuje się Agencja Europejskiej Straży Granicznej i Przybrzeżnej - Frontex. Została powołana na podstawie rozporządzenia nr 2016/1624 z 14 LX 2016 r. $^{18}$, zastępującego poprzednie akty prawne normujące działalność Frontexu ${ }^{19}$. W 2017 r. to waśnie ona otrzymała najwięcej produktów SatCenu (474, co stanowiło $21 \%$ calości oferty) ${ }^{20}$ spośród podmiotów unijnych, mimo że Centrum Satelitarne umocowane jest w strukturze Europejskiej Służby Działań Zewnętrznych i w założeniu służy działaniom w ramach wspólnej polityki zagranicznej i bezpieczeństwa, Frontex zaś jest agencją funkcjonującą w przestrzeni wolności, bezpieczeństwa i sprawiedliwości UE. Taki stan rzeczy wynika

18 Rozporzqdzenie Parlamentu Europejskiego i Rady (UE) 2016/1624 z dnia 14 września 2016 r. w sprawie Europejskiej Straży Granicznej i Przybrzeżnej oraz zmieniajace rozporzqdzenie Parlamentu Europejskiego i Rady (UE) 2016/399 i uchylajace rozporzadzenie (WE) nr 863/2007 Parlamentu Europejskiego i Rady, rozporzadzenie Rady (WE) nr 2007/2004 i decyzje Rady 2005/267/WE, Dz.Urz. UE 2016, nr L 251.

19 Szerzej w: A. Gruszczak, Europejska wspólnota wywiadowcza..., roz. 6.

20 EU SatCen Annual Report 2017, Luxembourg 2018, s. 15. 
$\mathbf{z}$ rosnącego zapotrzebowania Frontexu na zobrazowanie satelitarne i powietrzne granic zewnętrznych państw członkowskich UE, stref przygranicznych oraz obszarów nasilonych ruchów migracyjnych, głównie w basenie Morza Śródziemnego i na Bałkanach.

Wzmożony napływ imigrantów do UE, obserwowany od 2013 r., osiągnął kulminację w drugiej połowie 2015 r. i wywołał głęboki kryzys polityczny, ideowy i humanitarny w UE. Brak efektywnej kontroli na niektórych odcinkach granic zewnętrznych UE, załamanie wspólnego europejskiego systemu azylowego, niezdolność do konsensualnego wypracowania polityki wobec napływających cudzoziemców (w szczególności procedur azylowych i relokacji), ograniczone efekty misji UE w rejonach natężenia ruchów migracyjnych (w szczególności w środkowej części Morza Śródziemnego) wytworzyły wysokie ryzyko negatywnego oddziaływania na bezpieczeństwo UE, a nawet poczucie bezpośredniego zagrożenia granic zewnętrznych, bezpieczeństwa wewnętrznego i ladu publicznego w państwach członkowskich UE.

W obliczu narastającej fali cudzoziemców przekraczających granice zewnętrzne UE w marcu 2015 r. Centrum Satelitarne zawarło porozumienie o wsparciu działań Frontexu $w$ formie dostarczania danych geoprzestrzennych i gotowych produktów analitycznych odnoszących się do sytuacji na granicach zewnętrznych oraz głównych szlakach migracyjnych ${ }^{21}$. Liczba analiz i raportów dostarczonych przez SatCen do Frontexu szybko rosła: od 177 w 2015 r. do 380 w 2016 r. i 474 w 2017 r. ${ }^{22}$

Współpraca SatCenu z Frontexem była częścią programu Copernicus realizowanego przez Komisję Europejską we współpracy z Europejską Agencją Kosmiczną i innymi interesariuszami projektu monitorowania Ziemi pod kątem środowiska naturalnego, zarządzania zasobami naturalnymi i bezpieczeństwa. W tej ostatniej dziedzinie Copernicus skupiał się na nadzorze nad granicami lądowymi i morskimi oraz obserwacji akwenów morskich przyleglych do terytorium państw członkowskich UE. Transmisja danych geoprzestrzennych dawala istotne wsparcie europejskiego systemu nadzoru granic - EUROSUR. System powstawał wieloetapowo w latach 2013-2015 w celu stworzenia kompleksowego mechanizmu gromadzenia, analizy i wymiany informacji dotyczących ochrony granic, w szczególności tworzenia krajowych obrazów sytuacyjnych, europejskiego obrazu sytuacyjnego oraz wspólnego przedgranicznego obrazu sytuacyjnego ${ }^{23}$. Istniejące w ramach systemu zdolności skupienia danych umożliwiają tworzenie kompleksowych obrazów sytuacyjnych na podstawie danych rozproszonych

\footnotetext{
21 Zob. EU SatCen Annual Report 2016, Luxembourg 2017, s. 15.

22 EU SatCen Annual Report 2015, s. 16; EU SatCen Annual Report 2016, s. 16; EU SatCen Annual Report 2017, s. 15.

${ }^{23}$ Zob. więcej na ten temat w: A. Gruszczak, Technologie satelitarne na rzecz bezpieczeñstwa Unii Europejskiej, , Kultura i Polityka" 2014, nr 16, s. 106-108.
} 
pochodzących z krajowych ośrodków koordynacyjnych, agencji UE (głównie SatCenu i EMSA) oraz źródeł otwartych. Co istotne, dzięki odpowiedniemu oprogramowaniu oraz transmisji danych w czasie rzeczywistym możliwe jest generowanie obrazów sytuacyjnych w formie interaktywnych, wielowarstwowych map, a także śledzenie obiektów w celu wykrycia działań zagrażających bezpieczeństwu UE, takich jak różnorodne formy przemytu towarów i osób.

\section{Wykorzystanie rozpoznania geoprzestrzennego do wsparcia}

\section{morskich operacji UE}

W obliczu wydarzeń generujących ryzyko nasilonych lub niekontrolowanych migracji, w szczególności narabskiej wiosny" 2011 r. i jej reperkusji, instytucje i organy UE odpowiedzialne za bezpieczeństwo i obronę, zarządzanie kryzysowe oraz bezpieczeństwo wewnętrzne i ochronę granic sygnalizowały rosnące zapotrzebowanie na dane geoinformacyjne, aktualne zobrazowanie sytuacyjne oraz analizy geoprzestrzenne w rejonach podwyższonego ryzyka, w szczególności w Afryce Północnej oraz na Morzu Śródziemnym i w Syrii. Początkowo w centrum uwagi znajdowała się Libia ze względu na wysoką intensywność konfliktu wewnętrznego, zbrojną interwencję NATO oraz konsekwencje humanitarne tej sytuacji, w szczególności masową emigrację i naplyw uchodźców do państw UE. Od 2015 r. uwaga przeniosła się na wschodnią część Morza Śródziemnego, w szczególności granicę morską między Grecją a Turcją, którą przekraczały setki tysięcy uchodźców. Obserwacja geoprzestrzenna oraz bieżąca analiza danych obrazowych i geoinformacyjnych stanowily istotny element reagowania kryzysowego i zarządzania operacyjnego podjętego przez odpowiednie instytucje i organy UE od początku "arabskiej wiosny".

W celu zintegrowania danych geoinformacyjnych i utworzenia całościowego obrazu operacyjnego wspierającego politykę bezpieczeństwa UE Europejska Agencja Obrony (European Defence Agency - EDA) we współpracy z SatCenem uruchomiła w 2014 r. projekt informacji geoprzestrzennej w celu wsparcia decydowania w operacjach (Geospatial Information to Support Decision Making in Operations - GISMO) ${ }^{24}$.W drugiej fazie realizacji projektu, w 2015 r. SatCen przekazal technologiczny demonstrator aplikacji GeohuB państwom członkowskim, a w trzeciej fazie, w czerwcu 2016 r., GeohuB

24 GISMO puts geospatial support to CSDP missions on the map, https://www.eda.europa.ew/infohub/press-centre/latest-news/2017/12/13/gismo-puts-geospatial-support-to-csdp-missions-onthe-map, 23 XII 2017. 
został zainstalowany w dowództwie operacyjnym EUNAVFOR MED w Rzymie ${ }^{25}$. Operacja Sophia, prowadzona od 2015 r. przez wielonarodowe siły EUNAVFOR MED, ma na celu ograniczenie napływu nielegalnych imigrantów, wsparcie libijskich straży granicznych w kontrolowaniu granicy morskiej i wód terytorialnych, a także działania ratownicze w środkowym akwenie Morza Śródziemnego. GeohuB dzięki latwemu interfejsowi, bezpiecznej transmisji danych i stale doskonalonemu oprogramowaniu do przetwarzania danych daje uprawnionym użytkownikom (sztabowi operacji Sophia, zalogom statków morskich i powietrznych uczestniczących w operacji, a także ekspertom wspierającym procesy decyzyjne) bieżący dostęp do obrazów sytuacyjnych w rejonie objętym działaniami operacyjnymi ${ }^{26}$. Szczególne znaczenie mają rozpoznanie, ocena i nadzór nad szlakami nielegalnych migracji, a także dróg przemytu towarów oraz siatek przestępczych trudniących się tym procederem ${ }^{27}$.

Wsparcie wywiadowcze udzielone przez agencje UE podczas operacji Sophia czerpało $z$ doświadczeń wcześniejszej morskiej operacji sił UE, prowadzonej od 2008 r. u wybrzeży Somalii. Celem sił morskich EU NAVFOR Somalia w ramach operacji Atalanta byla ochrona przed atakami piratów na obiekty pływające (glównie statków handlowych) na Morzu Arabskim przemierzającymi szlaki wzdłuż wybrzeża Somalii, a następnie, od 2012 r., zwalczanie piractwa morskiego na wybrzeżu i wodach terytorialnych Somalii. W 2009 r. Centrum Satelitarne UE zostało zaangażowane we wspieranie operacji Atalanta w formie pozyskania od państw członkowskich UE obrazów satelitarnych obejmujących bazy pirackie, obiekty infrastruktury technicznej, instalacje portowe, linię wybrzeża, a także jednostki pływające, w szczególności lodzie rybackie, używane przez piratów do ataków na statki handlowe. Przeanalizowane dane geoinformacyjne trafialy $w$ formie produktów wywiadowczych do sztabu operacji Atalanta w Northwood, który dowodził unijnymi siłami morskimi w ramach tej operacji. Od 2012 r. obserwacją satelitarną objęto bazy lądowe piratów, a także uzbrojone oddziały w miastach wzdłuż wybrzeża Somalii. Poprawiono zdolności identyfikacji i dokładnej lokalizacji uprowadzonych statków handlowych ${ }^{28}$. Mimo że liczba incydentów morskich zdecydowanie spadła od 2014 r., SatCen regularnie dostarczał danych geoprzestrzennych i miał istotny wkład w tworzenie obrazów sytuacyjnych w rejonie działania sił EU NAVFOR Somalia.

\footnotetext{
25 EU SatCen Annual Report 2015, s. 21.

EU SatCen Annual Report 2017, s. 35.

27 Ibidem, s. 17.

Ibidem, s. 18.
} 


\section{Uwagi końcowe}

Rozpoznanie geoprzestrzenne jest istotnym składnikiem polityki bezpieczeństwa UE, coraz mocniej skupionej nie tylko na klasycznych wyznacznikach bezpieczeństwa narodowego państw członkowskich, lecz także elementach bezpieczeństwa humanitarnego, środowiska naturalnego oraz infrastruktury publicznej. Tworzenie strategicznej świadomości sytuacyjnej na podstawie kompleksowego systemu integrowania danych geoinformacyjnych ma istotne znaczenie dla skutecznego zarządzania bezpieczeństwem. Przedstawione w niniejszym rozdziale, siłą rzeczy skrótowo, elementy rozpoznania geoprzestrzennego UE $w$ ujęciu organizacyjno-instytucjonalnym wskazują na rosnącą potrzebę dostępu do informacji i wiedzy wzmacniającej procesy polityczne w obszarze bezpieczeństwa.

Podany w niniejszym rozdziale przykład Centrum Satelitarnego UE pokazuje, jak bardzo dane pozyskiwane przez obiekty satelitarne, powiązane $z$ informacjami pochodzącymi z obserwacji powietrznej Ziemi, kształtują potencjał wykrywania, identyfikowania i ostrzegania przed zagrożeniami i źródłami ryzyka. Podobnie ewolucja komponentu geoinformacyjnego $\mathrm{w}$ działalności agencji Frontex akcentuje dynamiczny wzrost zapotrzebowania na produkty wywiadu geoprzestrznnego w kontekście ochrony granic zewnętrznych oraz zarządzania kryzysem migracyjnym w Europie.

Postęp technologiczny oraz nakłady na badania i rozwój stymulują istniejący unijny potencjal rozwoju rozpoznania geoprzestrzennego do celów cywilnych i wojskowych. Przykładem może być wspomniana w kontekście projektu GISMO aplikacja sieciowa GeohuB. W kolejnych wersjach ma wzmocnić zautomatyzowane metody rozpoznawania obiektów, kodowania ich cech oraz - wykorzystując sztuczną inteligencję uzyskać złożoną świadomość sytuacyjną dzięki zastosowaniu algorytmów uczenia głębokiego ${ }^{29}$. Innym przykładem jest projekt analizy długoterminowej na podstawie stałego nadzoru (Persistent Surveillance Long Term Analysis - SULTAN), realizowany od 2014 r. wspólnie przez Europejską Agencję Kosmiczną i Europejską Agencję Obrony we współpracy $z$ wiodącymi przedsiębiorstwami zbrojeniowymi, na czele $z$ europejskim gigantem Airbus Defence and Space, zmierzający do budowy w perspektywie najbliższej dekady kompleksowego, złożonego, zaawansowanego technicznie systemu obserwacji i nadzoru. SULTAN w zamierzeniu wzmocni skuteczność zobrazowania geoprzestrzennego poprzez zintegrowane zdolności analizy danych geoinformacyjnych i danych powiązanych w celu wsparcia planowania i realizacji operacji wojskowych oraz misji zarządzania kryzysowego i ochrony granic ${ }^{30}$.

29 Ibidem, s. 26.

30 Persistent SUrveillance Long Term ANalysis (SULTAN), https://www.eda.europa.eu/what-wedo/activities/activities-search/persistent-surveillance-long-term-analysis-(sultan), 23 VIII 2018. 
Rosnące znaczenie GEOINT w polityce bezpieczeństwa, wzrost nakładów na badania i wdrożenie technologii i systemów, dążenie do integracji cywilnych i wojskowych systemów rozpoznania geoprzestrzennego, a także nacisk na proaktywne, uprzedzające zastosowanie produktów wywiadowczych to czynniki, które będą determinować w najbliższej dekadzie rozwój zinstytucjonalizowanej współpracy w dziedzinie rozpoznania geoprzestrzennego w UE.

\section{Bibliografia}

\section{Dokumenty}

Decyzja Rady 2014/401/WPZiB z dnia 26 czerwca 2014 r. w sprawie Centrum Satelitarnego Unii Europejskiej $i$ uchylenia wspólnego działania 2001/555/WPZiB w sprawie ustanowienia Centrum Satelitarnego Unii Europejskiej, „Dziennik Urzędowy Unii Europejskiej” 2014, $\mathrm{nr} \mathrm{L} 188$.

Meeting of the WEU Council of Ministers, Paris, 10 December 1990. Communique, http://www. weu.int/documents/901210-2en.pdf, 14 VI 2004.

Ministerial Decision setting-up of a WEU Satellite Centre taken at Vianden, Luxembourg, 27 June 1991, http://www.weu.int/documents/910627en.pdf, 14 VI 2004.

Rozporzadzenie Parlamentu Europejskiego i Rady (UE) 2016/1624 z dnia 14 września 2016 r. w sprawie Europejskiej Straży Granicznej i Przybrzeżnej oraz zmieniajace rozporzqdzenie Parlamentu Europejskiego i Rady (UE) 2016/399 i uchylajqce rozporzqdzenie (WE) nr 863/2007 Parlamentu Europejskiego i Rady, rozporzqdzenie Rady (WE) nr 2007/2004 i decyzje Rady 2005/267/WE, nziennik Urzędowy Unii Europejskiej” 2016, nr L 251.

U.S. Code, https://www.law.cornell.edu/uscode/text/10/467, 24 VIII 2018.

\section{Raporty i ekspertyzy}

EU SatCen Annual Report 2015, Luxembourg 2016.

EU SatCen Annual Report 2016, Luxembourg 2017.

EU SatCen Annual Report 2017, Luxembourg 2018.

\section{Monografie}

Bajerowski T., Kowalczyk A., Metody geoinformacyjnych analiz jawnoźródtowych w zwalczaniu terroryzmu, Olsztyn 2013.

Gruszczak A., Europejska wspolnota wywiadowcza. Prawo - instytucje - mechanizmy, Kraków 2014.

Gruszczak, A., Intelligence Security in the European Union. Building a Strategic Intelligence Community, London-New York 2016.

Heuer R. J. Jr., Psychology of Intelligence Analysis, Washington, D.C. 1999.

Liedel K., Serafin T., Otwarte żródla informacji w dzialalności wywiadowczej, Warszawa 2011. 


\section{Rozdzialy w pracach zbiorowych}

Molard B., How the WEU Satellite Centre could help in the development of a European intelligence policy, [w:] Towards a European intelligence policy, red. A. Politi, ${ }_{n}$ Chaillot Paper" ${ }^{n} \mathrm{nr} 34$, Institute of Security Studies of the WEU, Paris, December 1998.

\section{Artykuly w czasopismach naukowych}

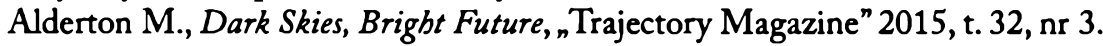

Barrowman R. E., Geospatial Intelligence. The New Intelligence Discipline, Noint Force Quarterly" 2007, nr 44.

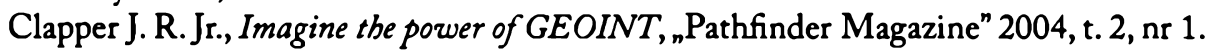

Gruszczak A., Technologie satelitarne na rzecz bezpieczeñstwa Unii Europejskiej, „Kultura i Polityka" 2014, nr 16.

\section{Źródla internetowe}

Geospatial Intelligence (GEOINT) Basic Doctrine, National Geospatial Intelligence Agency, Washington, D.C., September 2006, https://www.nga.mil/ProductsServices/ Documents/170901-038_GEOINT_Basic_Doctrine_Pub_1.pdf, 9 V 2014.

GISMO puts geospatial support to CSDP missions on the map, https://www.eda.europa.eu/infohub/press-centre/latest-news/2017/12/13/gismo-puts-geospatial-support-to-csdpmissions-on-the-map, 23 XII 2017.

National Research Council, Priorities for GEOINT Research at the National Geospatial-Intelligence Agency, Washington, D.C. 2006.

Persistent SUrveillance Long Term ANalysis (SULTAN), https:/www.eda.europa.eu/what-wedo/activities/activities-search/persistent-surveillance-long-term-analysis-(sultan), 23 VIII 2018.

Pleiades-HR (High-Resolution Optical Imaging Constellation of CNES), https://earth.esa.int web/eoportal/satellite-missions/p/pleiades, 24 VIII 2018.

Sentinel Satellites, http://www.copernicus.eu/main/sentinels, 24 VIII 2018. 
